\title{
砂浜における溶存態及び懸濁態物質の 土猿浸透に及ぼす漂着油の影響
}

\author{
鄭正朝 1 - 西嶋渉 2 - 馬場栄一 3 -岡田光正 4 \\ ${ }^{1}$ 工修 広島大学大学院 工学研究科博士課程後期（テ739-8527 広島県東広島市鏡山- - 丁目4-1） \\ 2工博 広島大学助教授 工学部環境基礎化学講座（干739-8527 広島県東広島市鏡山-..丁目4-1） \\ ${ }^{3}$ 工博広島大学教授工学部計数管理工学講座（テ739-0046 広島県東広島市鏡山三丁目 10-31, 広島大学地域共同センター) \\ 4正会員 工博 広島大学教授 工学部環境基礎化学講座（テ739-8527 広島県東広島市鏡山一丁目4-1）
}

\begin{abstract}
瀬戸内海等の静穏な海域に存在する傾斜の緩やかな砂浜を対象とし，漂着油の砂浜への土塞浸透とその漂 着油が溶存態及び眯濁態物質の土壌中への浸透に及ぼす影響を明らかにすることを目的として，モデル砂浜 を用いた実験を行った．原油と C 重油の浸透実験を行った結果，浸透した原油の $72 \%$ ， C 重油の) $98 \%$ \%゙ 土壤表面から $2 \mathrm{~cm}$ の部分に存在していることが確かめられた.この油の存在によって, 溶存態物質の浸透量 が低下し, 懸濁態物質の浸透が阻害されることが確かめられた. 以上のことは, 砂浜の底生生物の生存に不 可欠である溶存酸素, 栄養塩, 有機物のような溶存態物質と細菌, 植物プランクトン, シルトの上うな䀣濁 態物質の土䁃中への浸透が油の漂着によって阻害され, 底生生物に多大な影響を及ぼすと推測された。
\end{abstract}

Key Words : dissolved and particulate matters, stranded oil, wave action, sandy beach

\section{1. はじめに}

1989 年, アラスカ南岸でエクソンバルディース 号が座礁し，37,000 トンの原油が流出した 1).また， 1996 年にはイギリス Milford Haven で Sea Empress 号が座礁し, 約 72,000 トンの原油が流出する事故 があった 2). さらに, 1997 年には日本の沿岸域で起 きたナホトカ号の事故によって, 6,014 トンの重油 が流出した ${ }^{3)}$.

流出油の沿岸生態系への影響を考える場合, どの ような油が沿岸域に漂着するかが重要となる。流出 油のうち，急性毒性を持つとされる約 30-40\%の揮 発性成分の多くは沿岸に到達する前に蒸発によって 失われる ${ }^{4), 5)}$. エクソンバルディース号の事故によ って流出した 37,000 トンの油のうち, 約 35\%の揮 発性成分は蒸発によって失われ, 残りの約半分が沿 岸域に漂着したと報告されている ${ }^{6)-8)}$.

砂浜に漂着した油は, 土壤中の細菌, 原生動物等 の微生物とそれを餌とする線虫類, 二枚貝類, 甲壳 類, 多毛類, 腹足類等の底生生物に対して毒性を持 つことが知られている ${ }^{9}$. しかしながら, 油分が土 壌表面を覆うことによる付着藻類への光合成阻害 ${ }^{10)}$, 腹足類の飭摄取阻害 ${ }^{11}$ 等の間接的な影響の方が直接 的な毒性よりも砂浜生物に及ぼす影響は大きいと言 われている5).

砂浜土壌中の様々な底生生物の生息には, 波 ${ }^{12-14)}$

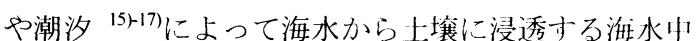
の植物プランクトン, 細菌, シルトのような懸濁態 物質, 酸素, 栄養塩, 有機物のような溶存態物質が 不可欠である 9)。漂着油は溶存並びに眯濁態物質の上 畩中への供給を阻害する可能性があるものの，漂着 油が海水中の溶存態及び懸濁態物質の土㙵浸透に及 ぼす影響を評価した研究は報告されていない.

そこで本研究では，瀬戸内海等の穏やかな海域に 存在する砂浜における海水から七壌中への物質移動 を支配する重要な因子として波に着目し，漂着油の 砂浜土壌への浸透と海水中の溶存態及び㐿濁態物質 の土壌への浸透に及ぼす漂着油の影響を明らかにす ることを目的とした。

\section{2. 実験方法}

\section{（1）実験装置}

本実験に用いた実験装置を Fig. 1 に示す。実験装 置は $0.9 \mathrm{~m} \times 0.6 \mathrm{~m}$ の観測空が付いた水槽（L $5.0 \mathrm{~m} \times$

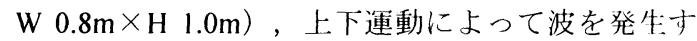
る造波装置, 潮汐制御装置, 温度調節装㯰, 販留 槽 $\left(4 \mathrm{~m}^{3}\right)$ から構成されて掞り, コンピューターシ ステムによって制御されている。潮汐変動 $(1 \sim 7$ 時間)，波周期（0.3〜3.0s），波高（最大 $50 \mathrm{~mm}$ ) 及び水温 $\left(0 \sim 30^{\circ} \mathrm{C}\right)$ の制御が可能である. 水槽の 左側に造波装置が設定されており，土壌は左側 


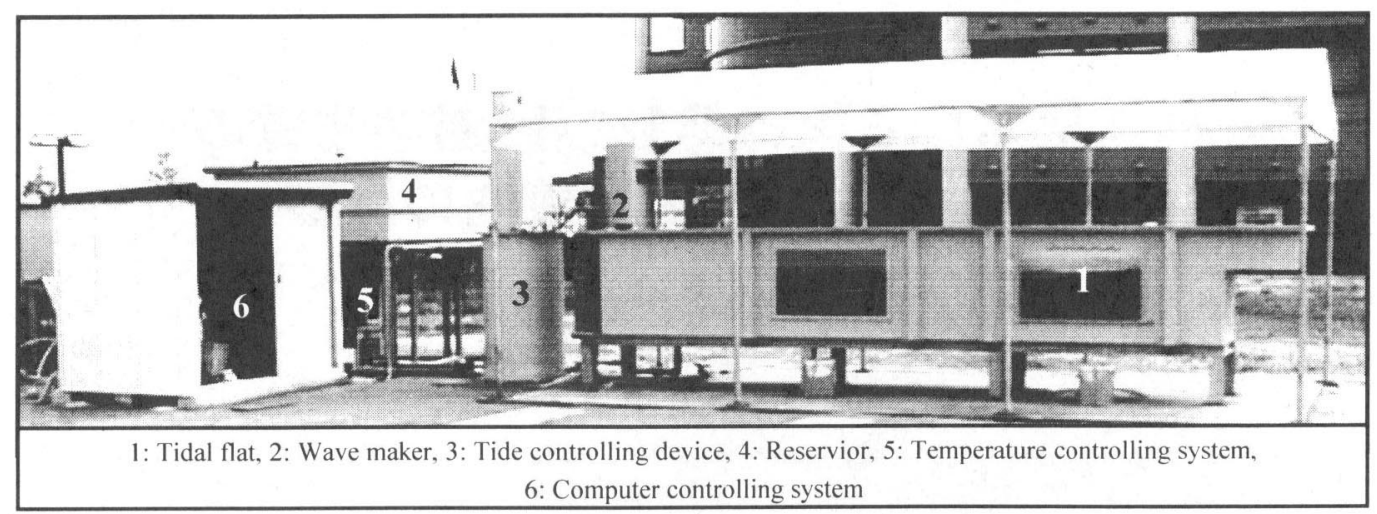

Fig. 1 Photograph of experimental set-up.

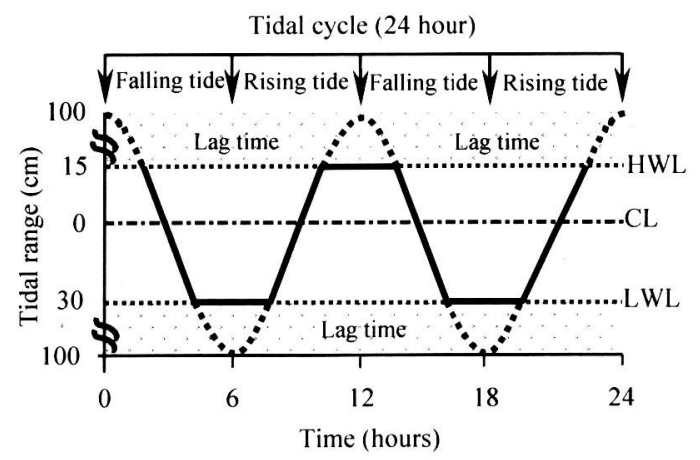

Fig.2 Tidal fluctuation. The dash line shows tidal range in present study. HWL : High Water Level, CL : Center Line, LWL : Low Water Level.

$0.5 \mathrm{~m}$ から充填されている. 土袞は通水性を持つしき り板 $(250 \mu \mathrm{m}$ メシュュ) によって保持し, 深さ $0.5 \mathrm{~m}$ まで充填した。 なお，左端で発達した波が装 置右端の壁にぶつかることによる反射波の発生を 除くため，右端にプラスチック製の積層網状マッ ト型の消波装置を設置した。

モデル砂浜の斜面勾配は10/100, 海水は塩分濃度 $35 \%$ の人工海水（MARINE-TEC. Co. Sealife）を用い, 水温は $15 \pm 11^{\circ} \mathrm{C}$ 範囲で制御した.

溶存態及び懸濁態物質土壤中への浸透を可視化寸 るため, 現場砂浜土壌の代りに透明なガラスビーズ を用いた。目本の砂浜土壤の中央粒径の $80 \%$ は 0.25 〜 $1.5 \mathrm{~mm}$ であること ${ }^{18)}$ から，ガラスビーズの粒径は 直径 $1 \mathrm{~mm}$ とした。

海水の土壤中への浸透は，斜面に直接ぶつかる時 の波の大きさ，すなわち砕波の大きさ（ $\mathrm{Hb}$ ： breaking wave height）に影響される ${ }^{19)}$. 本研究でも 砕波波高を波の基準にし, 溶存態及び懸濁態物質の

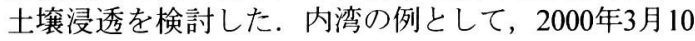
日中潮の時, 広島湾の江田島の沿岸で波を実測した 結果，砕波波高が $50 \mathrm{~mm} \sim 100 \mathrm{~mm} ，$ 周期が $0.8 \mathrm{~s} \sim 2.8 \mathrm{~s}$ の 範囲であったことから，本実験では砕波波高 $50 \mathrm{~mm}$,
Table 1 Physico-chemical properties of crude oil and fuel oil C.

\begin{tabular}{ccc}
\hline \hline Items & Crude oil & Fuel oil C \\
\hline \hline Viscosity at $15^{\circ} \mathrm{C}\left(\mathrm{mm}^{2} / \mathrm{s}\right)$ & 28 & 3750 \\
Specific gravity at $15^{\circ} \mathrm{C}\left(\mathrm{g} / \mathrm{cm}^{3}\right)$ & 0.87 & 0.95 \\
Pour point $\left({ }^{\circ} \mathrm{C}\right)$ & -15 & -10 \\
Sulfur content $\quad \% \mathrm{wt})$ & 2.00 & 2.15 \\
Water content $\quad \% \mathrm{vol})$ & 0.1 & 0.1 \\
\hline \hline
\end{tabular}

波の周期 $0.8 \mathrm{sec}$ (本砂浜装置で砕波ができやすい周期 として選んだ。）を標準的な実験条件とした。

本装置における潮汐変動速度は気象庁が発行寸る 広島湾の潮汐表から決定した ${ }^{20)}$. すなわち, 干潮か ら満潮までの平均水位変動時間 6 時間 13 分と平均 潮汐変動幅 $203 \mathrm{~cm}$ から, 潮汐による水位の上下変動 速度は $0.009 \mathrm{~cm} / \mathrm{s}$ とした. 潮汐変動はシミュレータ 一を砂浜の中央部分として想定し, Fig.2 に示すよう に 1 日 2 回ずつ下げ, 上げ潮を設定した。潮汐変動 幅は広島湾の潮汐変動幅 $203 \mathrm{~cm}$ をシミュレーター内 で再現することができない，物質移動に及ぼす波及 び潮汐の影響は土壤面と水位が一致する前後で大き く, 完全に冠水した状態, 干出状態の影響は小さい と考えられる.そこで Fig.2 に表した CL を中心に $45 \mathrm{~cm}$ (斜面中央から上 $15 \mathrm{~cm}$, 下 $30 \mathrm{~cm}$ の範囲）を シミュレーター内に再現した。但し, 冠水時間, 干 出時間は忠実に再現した。

\section{（2）溶存態，颚濁態トレーサー及び使用油}

海水中の溶存酸素, 栄養塩, 有機物のような溶存 態物質のトレーサーとしては比重が海水とほぼ等し い $0.02 \mathrm{M}$ 過マンガン酸カリウム水溶液 (赤色, 比 重: $1.01 \mathrm{~g} / \mathrm{cm}^{3}$ ) を, 植物プランクトン, 細菌, シル トのような懸濁態物質のトレーサーとしては粉末状 のアンスラサイト (黒色, 比重 $1.5 \mathrm{~g} / \mathrm{cm}^{3}$, 粒径 $75 \mu \mathrm{m}$ 以下）を使用した。1 回に投与した溶存態及び懸濁 態トレーサーの量は可視化できる範用とし, それぞ れ $25 \mathrm{ml}, 3 \mathrm{~g}$ とした。

中東産の UPPER ZAKUM 原油と C 重油の 2 種類 
( $123 \quad$ Number of tidal cycles

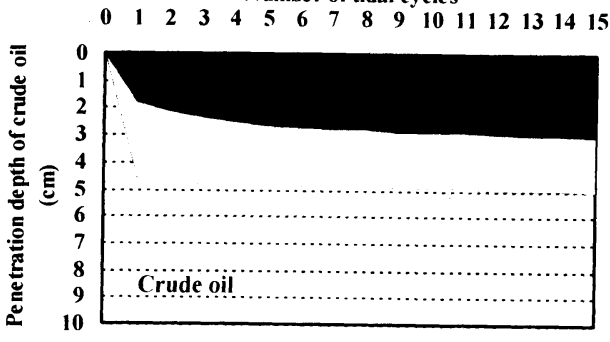

Number of tidal cycles

$\begin{array}{lllllllllllllllll}0 & 1 & 2 & 3 & 4 & 5 & 6 & 7 & 8 & 9 & 10 & 11 & 12 & 13 & 14 & 15\end{array}$

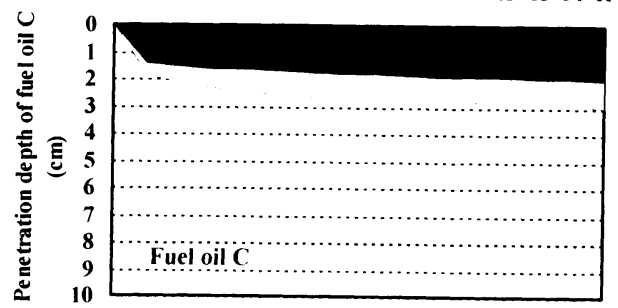

Fig. 3 Penetration of crude oil (top) and fuel oil C (bottom) into the sediments. Blacks and gray colors show colors of penetrated oils into transparent glass beads.

（興垔石油株式会社）を用いた。使用した原油と C 重油の物理化学的性質を Table1 に示す. $15^{\circ} \mathrm{C}$ にお ける原油の動粘度は $28 \mathrm{~mm}^{2} / \mathrm{s}$ で, C 重油は $3750 \mathrm{~mm}^{2} / \mathrm{s}$ であつた。比重は原油と C 重油がそれぞれ $0.87 \mathrm{~g} / \mathrm{cm}^{3}, 0.95 \mathrm{~g} / \mathrm{cm}^{3}$ である.

\section{（3）漂着油の土壤中への浸透}

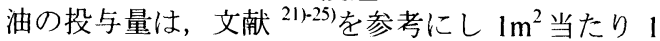
1とした。モデル砂浜土壤表面に油を均一に漂着さ せるため, 満潮位（HWL: High Water Level）の時に, 油を添加して水面全体に拡散させた。その後，水位 のみを下げて土袞表面に油を均一に漂着させた。

漂着した油の土壤中への浸透は，波と潮汐が同時 に作用する条件下で，15潮汐間にわたつてビデオ撮 影した。撮影した映像から漂着油の浸透深さと色の 変化を解析した。

また, 内径 $5 \mathrm{~cm}$, 長さ $25 \mathrm{~cm}$ のアクリルコアを用 いて土壤試料を採集した。土壤は表面から $2 \mathrm{~cm}$ ずつ 切り，その各々を均一に混合した後ジクロロメタン で抽出し，TLC - FID（(株)ヤトロン, IATROSCAN MK5）を用いて油分濃度を分析した ${ }^{26)}$ 。分析対象 と同一の原油と C 重油を標準とし, その重量で定量 化した.

\section{（4）溶存態及び晸濁態物質の浸透とその浸透に及 ほす漂着油の影電}

比較対象として，まず油が漂着してない通常の条 件下で，波による溶存態及び懸濁態トレーサーの土 壌中への浸透挙動を調べた。水位を一定にし，実験 開始直前にピペットを用いてトレーサーを土壤表面 に流した。その後波を造り，波によって浸透して行

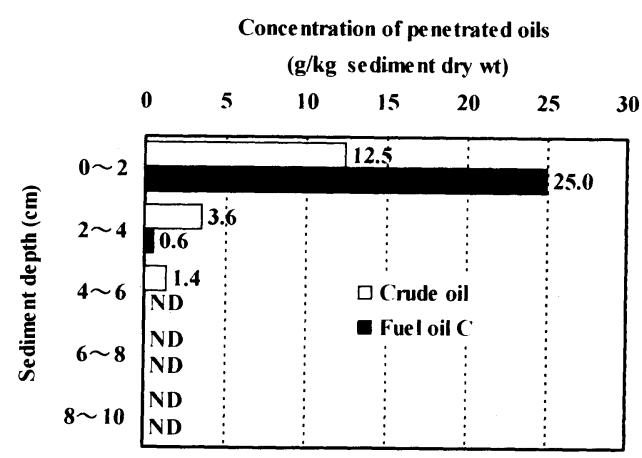

Fig. 4 Concentration of penetrated oil in the sediments at 15 th tidal cycle determined by TLC-FID. ND) not detected.

くトレーサーの移動をシミュレーターの空から観測 した. 同時に，その移動をビデオカメラ (SONY Co. Digital Handy Camera DCR-VX1000) で撮影した。 ビ デオ映像から，面積及び長さが解析できるソフト

(Planetron Co. LTD. Image-Pro Plus) を用い時間経 過に伴い土㙵中に浸透したトレーサーの面積を求め) た。そして，それを浸透面積の時間変化量，才な⿰ ち浸透速度 $\left(\mathrm{cm}^{2} / \mathrm{s}\right)$ として算出した27, 28

一方，士䁃表面に漂着した油が時閒経過と其によ 壤中に浸透して行くことにつれて溶存態及び懸濁態 物質の土壤浸透が異なると考え, 油が漂着してから 15潮汐間にわたって溶存態及び懸濁態トレーサーの 土塞浸透を観察した。トレーサーは2潮汐間隔で投 与した。トレーサーの浸透速度は油が漂着してない 条件と同様な方法で定量化した。

\section{3. 結果及び考察}

\section{（1）漂着油の土壤中への浸透}

満潮位に水面に油を投与し, 潮汐変動, 造波を開 始した。潮汐を重ねるにつれてガラスビーズ十壇表 面に付着した油の土䗙内部八の浸透が観察された。 油の浸透により，その存在量が大きいと推測される 黒色域と油の下部に油の存在量が比較的小さいと推 測される茶色域が表れた。

Fig. 3 に 15 潮汐間の黑色域と茶色域の深さお问の 変化を示す。漂着 1 潮汐目に扩ける原油の浸透深さ は，黒色域が $1.8 \mathrm{~cm}$ ，茶色域が $4.6 \mathrm{~cm}$ であつた。 方, C 重油の浸透深さは, 黒色域が $1.4 \mathrm{~cm}$, 茶色域 が $1.9 \mathrm{~cm}$ であった. 15 潮汐目において，原油の黑色 域と茶色域はそれぞれ $3.1 \mathrm{~cm}, 5.1 \mathrm{~cm}$ で，C重油の 方は $1.9 \mathrm{~cm}, 3.0 \mathrm{~cm}$ であった。1潮汐目に両油は急激 に土壤内部に浸透したものの，その以後は乙机ほど 大きな変化は見られなかった。 従って, 油の土壌浸 透には 1 潮汐目が最も重要であることがわかった。 また, C 重油に比べ原油の方がより深く土塨中に浸 透することがわかった。この両油の浸透深さの差は 粘度の違い $\left(15^{\circ} \mathrm{C}\right.$ での粘度, 原油; $28 \mathrm{~mm}^{2} / \mathrm{s}$, C 重 油； $3750 \mathrm{~mm}^{2} / \mathrm{s}$ ) によると推定される.

15 潮汐後にガラスビーズを深さ每に採集し, 各 層に存在する油の量を測定した。Fig. 4 に油分濃度 


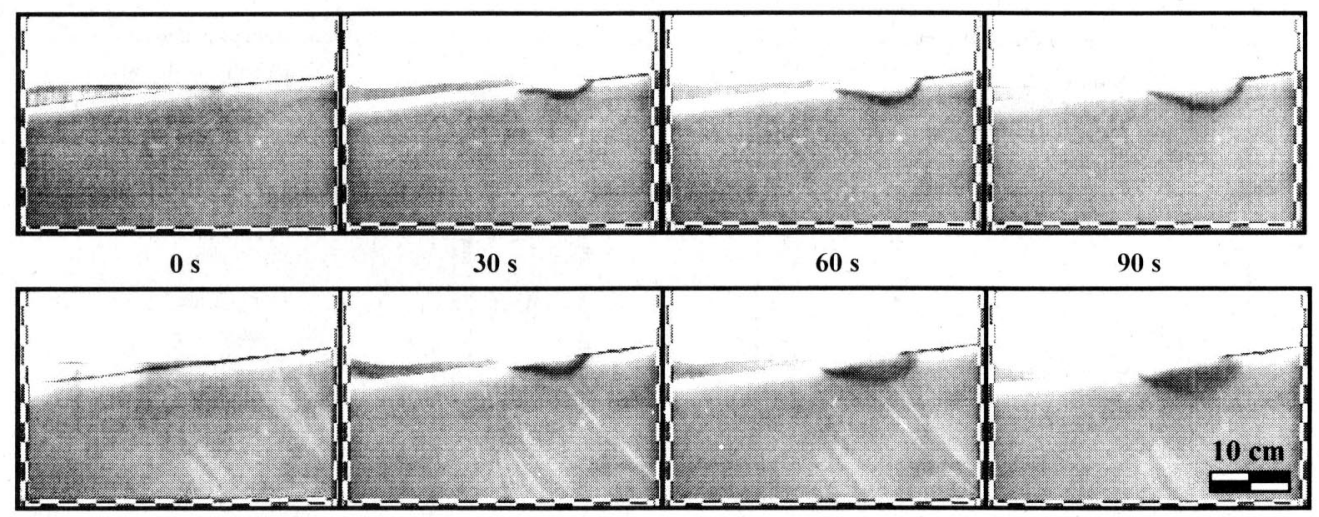

Fig. 5 Infiltration behaviors of dissolved (top) and particulate matters (bottom) by wave action.

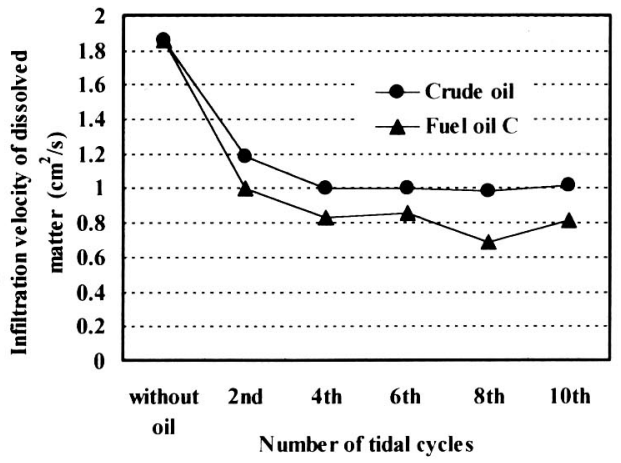

Fig. 6 Effects of penetrated oil on the infiltration of dissolved matter by wave action over tidal cycle.

の鉛直分布を示寸．浸透した原油の $72 \%$ ，C重油の $98 \%$ 土壤表面から $2 \mathrm{~cm}$ の部分に存在した。また, 15 潮汐目における観測值上実測值を比較すると大 まかにいって数 $\mathrm{g} / \mathrm{kg}$ 以上の油が存在する土㖶が黒 色域，その以下が茶色域として観察されたと考えら れる。

\section{（2）溶存態及び愳濁態物質の浸透挙動}

Fig.5 は溶存態並びに懸濁態トレーサーの土壤内部 八の浸透の時間的変化を示す。砂浜斜面で崩れた波 によって土壌表面の溶存態トレーサーは時間経過と 共に静止時の水面と砂浜の斜面が交差する点付近, 即ち，砕波の駆け上がり点（砕波が砂浜表面を駆け 上がる波の最大到達点）圭中心にして半円形状に土

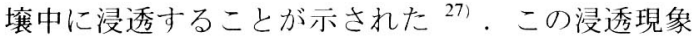
は，従来から知られている楔状に海水が浸透すると いう浸透理論 ${ }^{12)-14)}$ と全く異なっていた。

一方，懸濁態トレーサーの浸透挙動も溶存態トレ 一サーの浸透挙動と同様であり，砕波の駆け上がり 点を中心にして半円形状に土壤中に浸透した。浸透 速度 $2.66 \mathrm{~cm}^{2} / \mathrm{s}$ は溶存態トレーサーの浸透速度

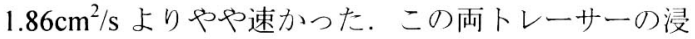

透速度の差異はそれらの比重の違い（溶存態トレー サー； $1.01 \mathrm{~g} / \mathrm{cm}^{3}$ ，戀濁態トレーサー； $\left.1.5 \mathrm{~g} / \mathrm{cm}^{3}\right)$ に よって生じたものと推測された。

\section{（3）溶存態物質の浸透に及ぼす漂着油の影響}

Fig.6に水位を一定に保った条件下での波による溶 存態物質の浸透速度に及ぼす漂着油の影響を示寸。 溶存態物質の土壌浸透には砂浜の勾配が大きく影響 を及ぼすが 27)，油の有無にかかわらず底質の移動を 伴うな粒子の動きは認められなかった。油が漂着し てない場合の海水浸透速度は $1.86 \mathrm{~cm}^{2} / \mathrm{s}$ であった。 しかし，油漂着後 2 潮汐目には，原油では $1.18 \mathrm{~cm}^{2} / \mathrm{s}$, $\mathrm{C}$ 重油では $1.00 \mathrm{~cm}^{2} / \mathrm{s}$ に浸透速度が大幅に減少した。 さらに，4 潮汐では浸透速度が，原油は $1.00 \mathrm{~cm}^{2} / \mathrm{s}$, $\mathrm{C}$ 重油は $0.83 \mathrm{~cm}^{2} / \mathrm{s}$ に減少した。しかし，それ後の 浸透速度には大きな変化が見られなかった。原油上 C 重油が漂着してから 10 潮汐後では浸透速度がそ れぞれ $1.01 \mathrm{~cm}^{2} / \mathrm{s}, \quad 0.81 \mathrm{~cm}^{2} / \mathrm{s}$ となり, 溶存態卜レ一 サーの浸透量は原油の漂着によって約 $1 / 3$, C 重油 の漂着によって $1 / 2$ 程度に減少した。

以上のことから, 砂浜に漂着した油は溶存酸素, 栄養塩, 有機物のような溶存態物質の土壤中への浸 透量の減少を引き起こすことが明らかとなった。

\section{（4）頌濁態物質の浸透に及ぼす漂着油の影響}

Fig.7 に水位を一定に保った条件下での波による䀣 濁態物質の浸透に及ぼす漂着油の影響を示寸。上図 に油が漂着してない場合を，下図に油が漂着してか ら4 潮汐目の䀣濁態トレーサー浸透を示した。実験 期間中懸濁態トレーサーの浸透状態には大きな変化 が見られなかったので代表として 4 潮汐目の浸透状 態のみを示した。

油が漂着してない場合，眯濁態トレーサーは時間 経過と共に半円形状に上壌内部に浸透したが，

Fig.7の下に示したように原油の漂着によって愳濁態 トレーサーはほとんど土壤中に浸透しなからた。さ らに300 秒間波を当て続けたが䀣濁態トレーサーの 浸透は起こらなかった。C重油を用いた実験でも全 く同じ結果が得られた。

砂浜に漂着した油は瞇濁態物質の土㙵浸透をほぼ 


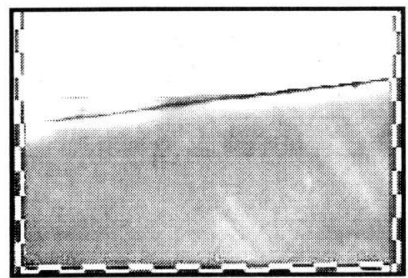

$0 \mathrm{~s}$
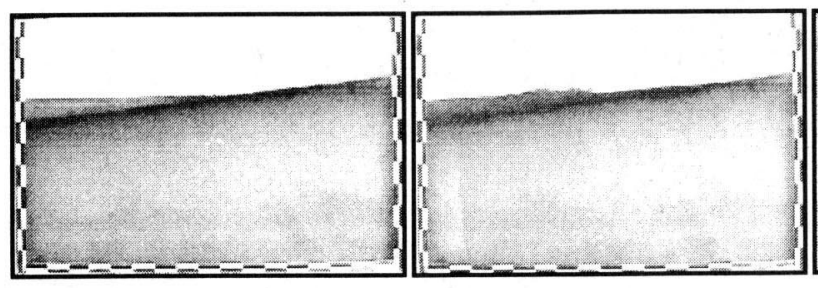

Fig.7 Comparison of settling of particulate matters between through the unoiled (top) and oiled (bottom. 4th tidal cycle) porous media over the tidal cycle.
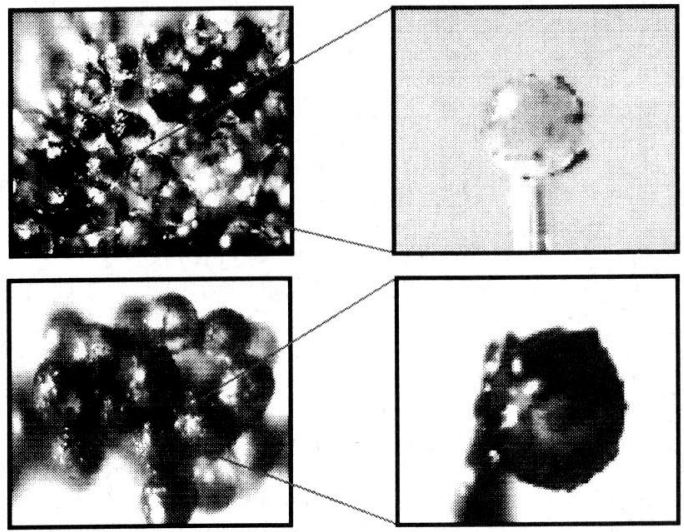

Fig.8 Adhesion of particulate matters on the glass beads coated by crude oil (top) and fuel oil C (bottom). The diameter of glass bead is $1 \mathrm{~mm}$.

\section{完全に阻害寸ることがわかった。}

Fig. 8 汢油が漂着してから 4 潮汐目のガラスビーズ 表面を撮影したものである。原油又は C 重油が土壤 表面に漂着することによって形成されたビーズ表面 の粘着性の油膜に䀣濁態粒子が付着していることが 観察された。従って, 䋰濁態物質はビーズ表面の油 膜に付着することによって土袞内部に浸透できなか ったと推定される.

以上のように，砂浜に漂着した油は溶存物質の浸 透速度を減少させ, 懸濁態物質としての細菌, 植物 プランクトン，シルトの浸透を阻害することから， 砂浜土壤中に生息寸る生物の慨の減少, 酸素, 栄養 塩の久乏を引き起こし, 砂浜生態系に多大な悪影響 を及ぼすと考えられる。

\section{4. まとめ}

そこで本研究では, 海水から土䁃中への物質移動 を支配する重要な因子として波に着目し, 漂着油の 砂浜土壤一の浸透と海水中の溶存態及び懸濁態物質 の土壌への浸透に及ぼす漂着油の影響を明らかにす ることを目的とした。そのため，波による溶存態及 び懸濁態物質の土㗒中への浸透把握, 漂着原油之 C 重油の土壤浸透の比較, 溶存態及び懸濁態物質の浸 透に及ぼす原油と $\mathrm{C}$ 重油の影響を検討した結果，以 下のことが明らかになった。

砂浜を想定した条件下で, 物理化学的性質が異な る原油と C 重油の浸透実験を行った結果, C 重油に 比心原油の方がより深く土蚈中に浸透したが，浸透 した原油の $72 \%$ が，C 重油の $98 \%$ が㗒表面から $2 \mathrm{~cm}$ の部分に集中して存在していることが確かめら れた。土壌に漂着した油は, 溶存態物質の浸透量を 低下させ，懸濁態物質の浸透を阻害した。

以上の結果は, 砂浜の底生生物の生存に不可欠で ある溶存酸素, 栄養塩, 有機物の上うな溶存態物質 と細菌，植物プランクトン，シルトのような愳濁態 物質の土壤中への浸透が油の漂着によって阻害され, 酸素不足, 飭の欠乏などによって底生生物に多大な 影響を及ぼすと推測された。

本研究では, 粒径がほぼ均一の球形ガラスビーズ で構成されたモデル砂浜を用いて, 溶存態及び懸濁 態の湾内砂浜の土壌内浸透に及ぼす波上漂着油の影 響を把握した。今後は実際の土䁃構造に合わせ，か つ風化が進んだ油を用いて現象の理解をさらに染め る必要がある。

謝辞 : 本研究は日本学術振興会未来開拓学術研究推 進事業「環境負荷の影響評価々軽減」の中, 研究プ 口ジェクト「沿岸油濁の生態系に与える負荷の評価 とその軽減」の一噮として実施したものであり,こ こに記して謝意を表します。 


\section{考文献}

1) Swannell, P. J., Lee, K. and Mcdonagh, M.: Field Evaluations of Marine Oil Spill Bioremediation, Microbiological Reviews, Vol. 60, No. 2, pp. 342-365, 1996.

2) Stationery Office. : The Environmental Impact of the Sea Empress Oil Spill, Final Report of the Sea Empress Environmental Evaluation Committee, The Stationery Office, London. pp. 1-25, 1998.

3）岡市友利: 石油流出事故による沿岸海洋污染-影響評価 と対策技術-, 水環境学会誌, Vol. 20, No. 10, pp. 632-638, 1997

4) Sebastiao, P. and Soares, C. G. : Modeling the Fate of Oil Spill at Sea, Spill Science \& Technology Bulletin, Vol. 2, pp.121-131, 1995.

5) Raffaelli, D. and Hawkins, S. : 潮間帯の生態学（朝倉彰 訳）文一総合出版, pp.68-83, 東京, 1996.

6) The Stationery Office. : The Environmental Impact of the Sea Empress Oil Spill, Final Report of the Sea Empress Environmental Evaluation Committee, The Stationery Office, London, pp.7-25, 1998.

7) Owens, E. H. : Changes in shoreline oiling conditions $1 \quad 1 / 2$ years after the 1989 Prince William Sound spill, Technical Report, Wooddward-ClydeConsultants, Coastal Science and Engineering Center, Seattle. 1991.

8 ) Galt, J. A., Lehr, W. J. and Payton, D. L. : Fate and transport of the Exxon Valdez oil spill. Environmental Science and Technology, Vol. 25, 202-209, 1991.

9）細川恭史，桑江朝比呂：干潟実験装置によるメソコス 厶実験, 上木学会論文集. Vol. 82, PP. 12-14. 1997.

10）緒方正名，藤澤邦康：石油による海洋污染と環境及 び生物モニタリング.日本水産資源保護協会, 東京, pp. $15-42,1991$.

11) Samiullah, Y. : Biological Effects of Marine Oil Pollution, Oil \& Petrochemical Pollution. Vol. 2, pp. 235-264, 1985.

12) McLachlan, A. : A Model for the Estimation of Water Filtration and Nutrient Regeneration by Exposed Sandy Beaches. Marine Environmental Research. Vol. 6. pp. 37-47, 1982.

13) Riedl, R. J. : How Much Seawater Passes through Sandy Beaches?, Internationale Revue der gesamten Hydrobiologie. Vol. 56, pp. 923-946, 1971.

14) Riedl, R. J., Huang. N. and Machan, R. : The Subtidal Pump: a Mechanism of interstitial Water Exchange by Wave Action, Marine Biology, Vol. 13, pp. 210-221, 1972.

15) Drabsch, J. M., Parnell, K. E.. Hume, T. J. and Dolphin T. J. The Capillary Fringe and the Water Table in an Intertidal Estuarine Sand Flat, Estuarine, Coastal and Shelf Science. Vol. 48, pp. 215-222, 1999.

16) Rocha. C. and Cabral, A. P. : The Influence of Tidal action on
Porewater Nitrate Concentration and Dynamics in Intertidal Sediments of the Sado Estuary. Estuaries. Vol. 21. pp. 635-645. 1998.

17) Asmus, R. M., Jensen, M. H.. Jensen. K. H.. Kristensen. E., Asmus, H. and Wille, A. : The Role of Water Movement and Spatial Scaling for Measurement of Dissolved Inorganic Nitrogen Fluxes in Intertidal Sediments. Estuarine, Coastal and Shelf Science, Vol.46, pp. 221-232. 1998.

18）坂本市太郎：砂浜の潮汐に伴う吸收（有機物け好父分 解代謝）機能，用水之廃水, Vol. 36, pp.44-52. 1994.

19) McLachlan, A. : Water Filtration by Dissipative Beaches. Limnology and Oceanography. Vol. 34.pp. 774-780. 1989.

20）日本気象協会中国センター：潮汐表，広島県漁業協[间 組合連合会, p.37, 1997.

21) Delaune, R. D. : Effect of Oil on Salt Marsh Biota: Methods for Restoration. Environmental Pollution. Vol. 36. pp. 207-227, 1984.

22 ) Lin, Q. and Mendelssohn. I. A. : A Comparative Investigation of the Effects of South Louisiana Crude ()il on the Vegetation of Fresh, Brackish and Salt Marshes. Marine Pollution Bulletin. Vol. 32. No. 2. pp. 202-209. 1996.

23 ) Little, D. I. : The Physical Fate of Weathered Crude and Emulsified Fuel Oils as a Function of Intertidal Sedimentology. Fate and Effects of Oil in Marine Ecosystems. Martinus Nijhoff Publishers, Printed in the Netherlands, p.3-18. 1987.

24) Oudot, J.. Merlin. F. X. and Pinvidic. P. : Weathering Rates of Oil Components in a Bioremediation Experiment in Estuarine Sediments. Marine Pollution Bulletin. Vol. 45, No. 2, pp. 113-125, 1998.

$25)$ Smith, C. J., Delaune. R. D. and Patrick, W. H. : ^ Method for Determining Stress in Wetland Plant Communities Following an Oil Spill. Environmental Pollution, Vol. 26. pp. 297-304. 1981.

26) Robert, M. G.. Ingrid, J. P.. Copper. E. H. and Roger. C' P. : Photooxidation of Crude Oil. Environmental Science and Technology, Vol. 32. pp. 3719-3723. 1998.

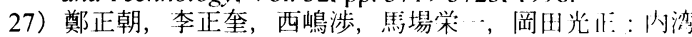

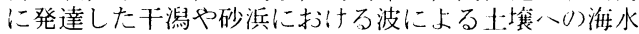
の浸透，水環境学:会誌，Vol. 23. No. 10.pp. 619-623. 2000.

28) Cheong, C. J., Cho. K. J.. Nishijima. W.. Baba. L. and Okada, M. : Effects of spilled oil on the tidal flat ecosystem-evaluation of wave and tidal actions using tidal flat simulator-, In 1st World Congress of the International Water Association. 3-7 July 2000. Paris France. Book 1. Industrial wastewater treatment. pp. 469-475, 2000.

(2000.7.12 受付)

\section{INFLUENCE OF STRANDED OIL ON THE INFILTRATION OF DISSOLVED AND PARTICULATE MATTERS INTO SANDY BEACH SEDIMENTS}

\section{Cheong Jo CHEONG, Wataru NISHIJIMA, Eiichi BABA and Mitsumasa OKADA}

The objective of this study is to clarify the penetration behavior of spilled oil stranded on sandy beach and to evaluate the effects of the penetrated oil on the infiltration of dissolved and particulate matters by wave action into sandy beach sediments. The penetration depth of stranded crude oil was deeper than that of fuel oil C. which caused by the difference in viscosity between those two oils. Most of the applied oils penetrated into the sediments. Seventy-two percent of crude oil and $98 \%$ of fuel oil C in penetrated oil remained in $2 \mathrm{~cm}$ depth from the surface. The penetrated oil significantly reduced the infiltration of dissolved and particulate matters into the sediments. These results indicate that the penetrated oil prevents the infiltration of both dissolved and particulate matters into the sediments and, therefore, results in the reduction in the supply of oxygen, nutrient, and organic matters for the benthic organisms in the sandy beach. 